\title{
Development and Urgency of Public Services through E-Government in the Middle of Pandemi Covid-19
}

\author{
Syahrul Ibad \\ Dept. Law, Ibrahimy University \\ Sukorejo Sumberejo Banyuputih Situbondo East Java, Indonesia \\ E-mail: sinbad.sit@gmail.com \\ Yona Wahyu Lolita \\ Dept. of information technology management, Ibrahimy University \\ Sukorejo Sumberejo Banyuputih Situbondo East Java, Indonesia \\ E-mail: yonawahyu78@gmail.com
}

Received: Oct. 25, 2020 Accepted: Nov. 27, 2020 Online published: Dec. 7, 2020

doi:10.5296/jpag.v10i4.17867～URL: https://doi.org/10.5296/jpag.v10i4.17867

\begin{abstract}
This research discusses and analyzes the new normal life in the era of the Covid-19 pandemic, thus a development and urgency of public services is needed in the midst of the Covid-19 pandemic that is able to answer technical problems of public services. The objective of this writing is to outline the development and the importance of public service through work system changes approach as well as the significance of public service development, which can reconstruct whether this system-based public service could really be implemented during the covid-19 pandemic. using descriptive research methods with a qualitative approach, methods used to describe or analyze a research result but not used to make broad conclusions. Thus it is found in this study the dimensions of the ASN work system change model, the development and urgency of e-government public services, and adjustments to the development of public services in the midst of the Covid-19 pandemic.
\end{abstract}

Keywords: public services, e-government, Covid-19 pandemic

\section{Introduction}

Public services are one of the important functions of government apart from regulation, protection and distribution. According to (Safroni, 2012) Public service is a process as well as 
an output that shows how government functions are carried out. As in Law Number 25 of 2009 Article 1 concerning public services, which states that public services are activities or a series of activities in the context of meeting service needs in accordance with statutory regulations for every citizen for goods, services and administrative services provided by public administrators. Meanwhile, according to (Dwiyanto, 2010) public services actually have a very wide range, including services to meet the needs of public goods, basic needs and rights, government obligations, and national commitments.

In the context of public service delivery, the government is the first and foremost factor that is responsible for the fulfillment of people's rights. This is done because public services are an inseparable part of the government's obligations for the welfare of its people. Therefore, the 1945 Constitution mandates the state to fulfill the basic needs of every citizen for their welfare so that the effectiveness of a government system is largely determined by good in bad of public administration. Increasing needs of the society make public servants better in providing services. This has led to public service innovations with a view to improving and enhancing public services.

Since the emergence of Corona Virus Diseases 2019 or what is known as Covid-19, it has become a problem which has captured the attention of many people in various parts of the world. Since it was first discovered from a patient infected with Covid-19 in Wuhan, Hubei Province, China on December 8, 2019, this virus has now spread to 216 countries (WHO, June 13, 2020). The Covid-19 pandemic has not only threatened human health, but has also affected the global economic downturn (Shangguan, Wang, \& Sun, 2020). The policies for implementing Regional Quarantine (Lockdown) and Social Distancing were enforced by countries in the world affected by the covid-19 pandemic. The implementation of this policy causes the society can't do direct interaction with one another. This aims to reduce the risk of transmission of covid-19, which is very easily transmitted from one person to another. This limitation of interaction causes the society to meet their needs cannot maintain conventional ways to obtain or fulfill their needs, including in public services. People inevitably have to turn to the use of online media.

The imposition of social restrictions in Indonesia also has an impact on the accessibility of public services which is difficult to do. Circular issued by the Minister of State Apparatus Empowerment and Bureaucratic Reform (PANRB) Number 19 of 2020 concerning Adjustments to the Work System of State Civil Apparatus in Efforts to Prevent the Spread of covid-19 within Government Institutions. This Circular Letter is used to enforce work from home in turn for employees in Government Agencies. This affects the accessibility of public services. Conventional services, namely face-to-face, begin to be limited in number and the rest is assisted by an online system. This online service is the result of the application of e-Government.

It is not an easy thing to make changes to the government sector, unlike the business sector which can change rapidly according to internal and external dynamics, the public sector usually has a very strong resistance to change. A similar condition is faced by Indonesia if it wants to implement e-government in regional government. The challenges that will be faced 
should not be avoided, but identified and solutions sought.

Changes which occur in the government bureaucracy, both due to internal bureaucratic needs and due to external pressure. This also occurs both at local and global levels, especially when the interaction between local and global conditions cannot be separated, global conditions affect the local situation, while local conditions also affect interactions between communities and between governments at the global level. Globalization has helped the development of the world through the exchange of ideas, commodities, knowledge and even technology (Sen, 2002: 16). This situation, in the context of governmental organizations, certainly brings some changes in life and organizational structure.

In 2020, Deborah Agostino, et.al, argued that the covid-19 pandemic had an impact on the development of digital transformation in public service delivery in Italy. The social challenges that emerged after the outbreak of the covid-19 pandemic forced public institutions or government institutions to carry out digital acceleration to optimize public services (Debora, et. Al., 2020). From this research, it is important to examine the development and excellence of public services in the midst of the covid-19 pandemic.

The implementation of the new normal forces people in Indonesia to be able to return to their activities outside the home, coupled with the risk of the covid-19 outbreak. Therefore, new normal has a different character from the normal situation before the covid-19 pandemic broke out. The Health Protocol to prevent the spread of the virus is still enforced and continues to be encouraged in every public service procedure. So it can be ascertained that conventional public services during the normal situation before the pandemic were not possible to apply to the New Normal. This has led to improved development and the urgency of implementing and accelerating e-government development by government agencies.

Situbondo district East Java province Country Indonesia since 2016 has started Study Feasibility and Assessment Roadmap e-government Situbondo, Presidential Instruction No. 3 of 2003 on National Policy and Strategy Development of e-government; East Java Governor Decree Number 36 of 2003 concerning the Implementation of the Information System and Telematics for the Province of East Java; Situbondo Regent Regulation Number 4 of 2012 concerning the Use of Legal Software and Utilization of Open Source Software (OSS) in the Situbondo district Government. So that during the covid-19 pandemic and the new normal, Situbondo district followed the direction of the Minister of State Apparatus Empowerment and Bureaucratic Reform (PANRB) Number 19 of 2020 concerning Adjustment of the Work System of State Civil Apparatus in Preventing the Spread of covid-19 in Government Institutions. This Circular applies work from home in turn for employees in Government Agencies. This affects the accessibility of public services. Conventional services, namely face-to-face, begin to be limited in number and the rest is assisted by an online system. This online service is the result of the application of E-Government.

This paper, the government is faced with the challenges new normal era in a pandemic era covid-19, so we need a development and public service in the middle of the urgency of the pandemic covid-19 capable of responding to problems-technical problems of public services . This paper aims to review the development and urgency of public services through the 
development model approach and the urgency of public services. So that bureaucratic changes require creative ideas that are developed through a public service, so that public services continue to run well, without obstacles even in the conditions of the COVID-19 pandemic.

\section{Methodology}

The research method used is descriptive research with a qualitative approach. According to Miles, Huberman and Saldana (2014) define descriptive research as a method used to describe or analyze a research result but is not used to make broad conclusions. The focus of this research is the development and urgency of public services through e-government in the midst of the Covid-19 pandemic. This research was conducted in Situbondo district using data collection carried out through interviews, observation, and documentation. Meanwhile, in qualitative data analysis, there are three activity lines following the steps of data condensation, data display, and conclusion drawing / verification in order to answer research problems.

This research is intended to try describing the design of a development model and the urgency of public services in the midst of the Covid-19 pandemic, the paradigm and approach of public services by using information technology which is in accordance with the needs of the society and for the prevention of covid-19 transmission, in particular constructing and reconstructing what is real system-based public services can be applied during the covid-19 pandemic. If implemented and developed through the e-government public service system, what kind of construction and reconstruction can be used in developing the system for public services, even in factual.

\section{Discussion}

\subsection{Dimensions of Work System Change}

One of the problems that arose with the implementation of WFH policies during the pandemic was that there were still a lot of OPDs and government agencies that were not ready to implement the WFH policies Purwanto (2020). Public services, which are usually carried out face-to-face, are not optimal because the existing system has not supported the implementation of online services (Krisyohana, 2020). From some of these problems, it shows that the WFH policy is not yet fully ready to be applied for ASN, considering the many complaints and problems experienced by ASN and government agencies. Therefore, it is necessary to make organizational changes during this pandemic, where according to Maria (1998) in Muchtar (2020) states that even organizational change is an activity that rearranges organizational instruments to achieve goals and efficiency and effectiveness in organizing. So it is necessary to conduct a more in-depth study regarding the readiness of ASN in implementing WFH policies.

Government policy is a decision step taken on a problem for the benefit of society. The term policy is often used interchangeably with other terms such as objectives, programs, decisions, laws, provisions, proposals and grand drafts. For policymakers these terms will not cause any problems because they use the same references. However for people who are outside the policy making structure the terms may be confusing (Darmawan, Septian, \& Pratama, 2017) 
To deal with the impact of the Covid-19 pandemic, the Government has taken several policies that have been implemented, one of which is about budget changes. In accordance with Government Regulation in Lieu of Law (Perppu) No.1 of 2020, the government has the authority to take actions that result in spending on the APBN where the budget for these expenditures is not yet available or insufficient. With the policies that have been taken by the government, there are several consequences that will be experienced by the society at large. Considering that this policy is a new policy which will certainly have an impact on several normal processes, usually from the government side. So that this will affect the public needs and political will of policy makers in government agencies and ASN in running the wheels of government. The implementation of this new work stem for ASN is a development that has been planned since 2019, but it is not yet optimal because there are pros and cons among the society. Since the occurrence of c ovid-19, the policy of working from home for ASN must be implemented, in order to prevent transmission of c ovid-19. In addition, the aim of implementing WFH during a pandemic is to ensure that all services can run well, and that the main duties and functions of the agency continue. The implementation of the WFH policy is supported by the Circular of the Minister of PANRB No. 19 of 2020 concerning Adjustments to the ASN Work System in Efforts to Prevent the Spread of covid - 19 in Government Agencies. With this regulation, regional leaders, in this case Civil Service Officers (PPK) and leaders of Government Agencies or Regional Apparatus Organizations (OPD), must carry out various kinds of innovations to continue providing public services to the society.

As state servants, the duties and functions of ASN in a new normal order are carried out by prioritizing health and safety aspects by implementing health protocols in their daily activities. There are three elements of concern in adaptation to the new normal order in the ministries / agencies / regions, namely: adjustment of the work system, human resource support, and infrastructure support (Kemenpan-RB, 2020) as follows:

a. Adjustment of the Work System ASN comes to work and complies with the prevailing working hour regulations. However, to adapt to pandemic conditions, it is necessary to make adjustments to the work system by implementing health protocols in daily activities. Adjustment of the working system could be implemented through flexibility in working location settings, namely the implementation of official duty at the office (work from office "WFO") or execution of official duty at home (work from home "WFH"). In the conditions of the Covid-19 pandemic, ASN can choose one of these work mechanisms in carrying out their duties as public service provider.

b. Human Resources Support for Apparatus Several things that need to be considered in the management of human resources in the apparatus including the performance appraisal by the official guidance personnel (PPK), monitoring and supervision by the head of the work unit, and PPK ensures employee discipline. Performance appraisal model, monitoring, and evaluating can be adapted to the conditions of pandemic c ovid-19. At least the model is built by considering the principles of flexibility and based on digitization.

c. Infrastructure support in adjusting to the new normal order, PPK was asked to prepare support for the facilities and infrastructure needed by ASN. In the implementation of 
official duties, the flexibility of working location can be considered and ensuring that the application of information technology in government administration and public services is carried out by taking into account the guidelines for the usage of information and communication technology, and information security and cyber security. This is important so that public services can run smoothly, but are safe from the crime of illegal access to data transmission.

Covid-19 pandemic conditions have changed many things in working life, including the bureaucracy. Facing the new normal situation, the government has made several adjustments to the new workspace, namely the process of designing bureaucratic changes by using various technological developments. There are five main components of changing the new work space of the bureaucracy according to Prasojo (2020), namely:

a. Flexible and networked workspace.

b. Infrastructure setup and super application (superapp) learning that enables virtual and digital offices. Change of new workspace that was previously carried out in office building, are now reduced in need in the new normal era.

c. Improved ASN capabilities in interacting with various advances in information and communication technology, including big data and artificial intelligence, is needed.

d. In the new era of the normal post- covid-19 structuring of business processes and workflows bureaucracy must be done immediately. There is a simplification of service procedures by utilizing digitalization-based services so that services to the society can be done easily and quickly.

e. The new normal era of bureaucracy requires qualified and competent ASN employees to manage new workspaces. The required ASN employees who are able to do various jobs quickly, not based on quantity, but quality.

The condition of the pandemic covid-19 has changed the paradigm of the ASN working system to be more effective and efficient, to be more results-oriented than procedural. ASN works to provide public services to the society with excellence in the midst of a pandemic covid-19. However, the health and safety of ASN has become a top priority during the covid-19 pandemic. Therefore, even though the new normal policy has been implemented, ASN still adheres to and carries out health protocols at work.

\subsection{Urgency Public Service Based Electronics in the Middle Covid-19}

When the Covid-19 outbreak emerged in Indonesia, the Situbondo Regency government faced a crisis situation that forced them to take drastic and strategic steps in efforts to contain the virus outbreak. One of the government's efforts is optimizing e-services for governance or what is called e-government. Through e-government, the government can improve the efficiency of public services and minimize the spread and transmission of covid-19 to the society. Services with e-government systems prioritize long-distance services via the internet (online) through government websites. As a public service institution, libraries are also required to apply e-government to improve digital information services to the public during the Covid-19 pandemic. 


\section{Ml Macrothink}

Journal of Public Administration and Governance ISSN 2161-7104

The provision of information with the e-government system in Situbondo district has been designed since 2016 and until the time of the covid-19 pandemic there were not many changes and developments, government agencies provided open access data and information, about accurate services and information as the basis for public health field decision making (Dong, Du, \& Gardner, 2020). In this covid-19 pandemic, public services can apply and implement e-government manner as Figure 1 below.

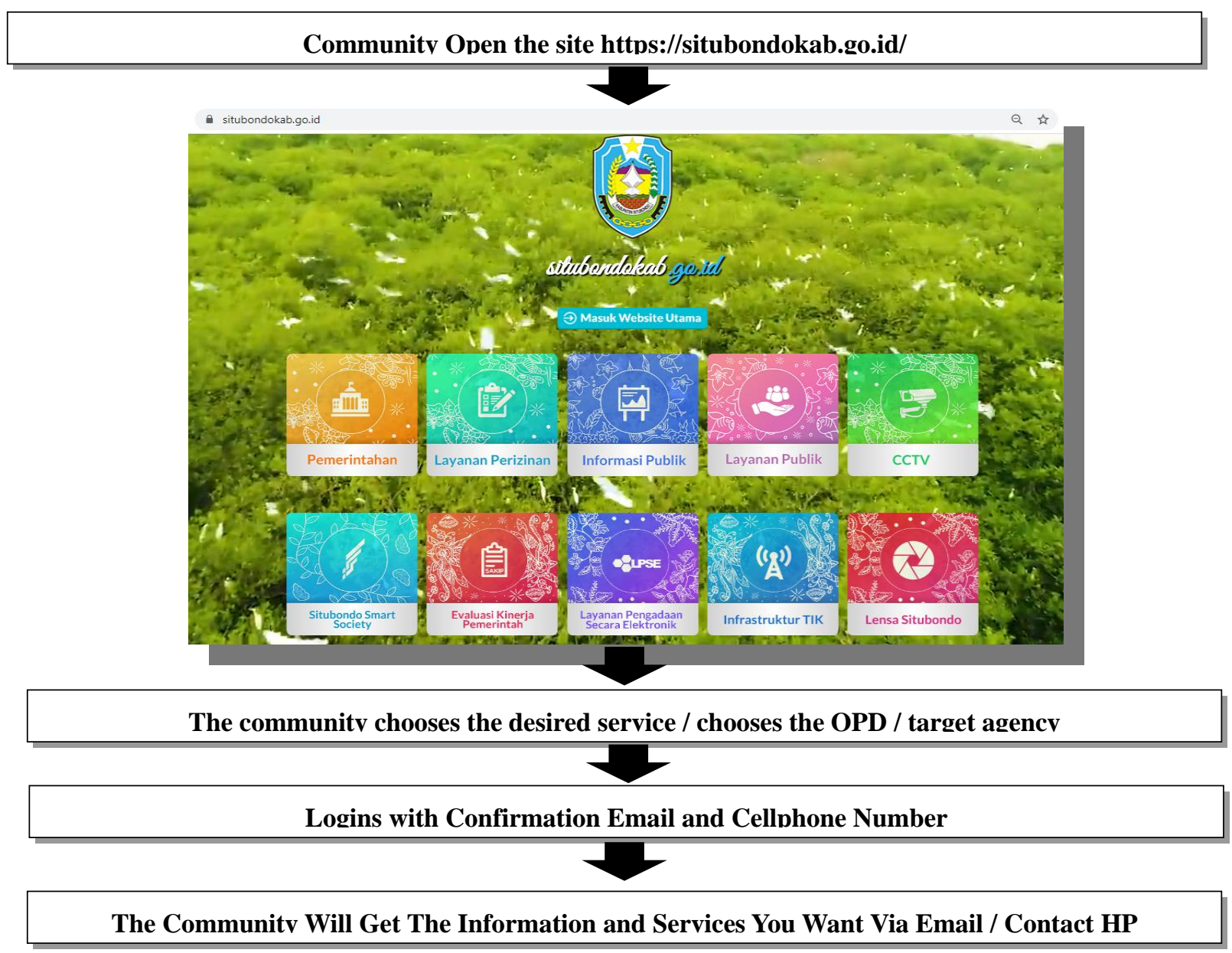

Figure 1. Flow of Public Service on the page https://situbondokab.go.id/

Situbondo public services future covid-19 pandemic maximize the services of e-government that are available to accommodate a wide range of services performed by the OPD and agency located in Situbondo. This service is classified as a Government to Citizens (G-to-C) application type, because it aims to build interaction between the government and its people. The Government to Citizens (G-to-C) application aims to bring government services closer to the people through various access channels with the aim that the public can easily reach their government in providing services. The Situbondo Regency public service is made in the form of an integrated website of each OPD and agency in the Situbondo district so that it is easily accessible at https://situbondokab.go.id/.

The change in public services from face-to-face services to e-government services during the Covid-19 pandemic, when it is viewed in agreement (Lewin, 1951) is an external force that 
demands to make changes in the body of the government itself. With the conditions of the Covid-19 pandemic, the government has turned public services to online. Despite the fact that in the field there are still problems caused by bureaucracy, such as convoluted bureaucracy, slow response, and hesitation in making decisions because they are not familiar with the new habits (online). Another fact can be found that there is a sectoral ego between DPOs and agencies, which is not in line, even contradicting each other in handling Covid-19 in Indonesia so that it has an impact on public services that still use conventional and online. Each ministry looks at the interests of their respective sectors (Kompas, 2020).

In setting and deciding development and public services urgency amid the pandemic covid-19, there is a policies which forms the basis by Situbondo in the service and management of information, which includes: (1) automation services such as applications for permission and others; (2) interactions and transactions via the website, such as payment of PDAM, SIM and other bills; (3) service integration, integrated data transfer activities with OPD and other agencies. These policies are like:

a. Law Number 23 of 2014 concerning Regional Government as amended several times, most recently by Law Number 9 of 2014;

b. Law Number 30 of 2014 concerning Government Administration;

c. Law Number 25 of 2009 concerning Public Services;

d. Law Number 14 of 2008 concerning Freedom of Information;

e. Law Number 11 of 2008 concerning Electronic Information and Transactions (State Gazette of the Republic of Indonesia of 2008 Number 58, Supplement to the State Gazette of the Republic of Indonesia Number 4843);

f. Law Number 36 of 1999 concerning Telecommunications;

g. Law Number 1 of 2004 concerning State Treasury;

h. Law Number 17 of 2003 concerning State Finances;

i. Government Regulation Number 82 of 2012 concerning Implementation of Electronic Systems within the Framework of the Indonesia National Single Window;

j. Government Regulation Number 38 of 2007 concerning the Sharing of Government Affairs between the Government, Provincial Government and, Regency / City Government;

k. Government Regulation Number 58 of 2005 concerning Regional Financial Management and Accountability;

1. Government Regulation Number 65 of 2005 concerning Guidelines for the Formulation and Application of Minimum Service Standards (State Gazette of the Republic of Indonesia of 2005 Number 150, Supplement to State Gazette of the Republic of Indonesia Number 4585);

m. Instructions President No. 3 of 2003 on National Policy and Strategy Development of e-government;

n. Regulation of the Minister of Home Affairs Number 13 of 2006 concerning Guidelines for Regional Financial Management as amended several times, most recently by Regulation of the Minister of Home Affairs Number 21 of 2011; 
o. Regulation of the Minister of Communication and Information Number 28 of 2006 concerning Use of the go. id Domain Name for the official website of the Central and Regional Government;

p. Regulation of the Minister of Communication and Information Number 41 of 2007 concerning General Guidelines for National Information and Communication Technology Governance;

q. Regulation of the Minister of Communication and Information Number 22 / PER / M.KOMINFO / 12/2010 concerning Minimum Service Standards in the Communication and Information Technology Sector in Regencies / Cities;

r. Decree of the Minister of State Apparatus Empowerment Number 13 / KEP / M.PAN / 2003 concerning General Guidelines for Electronic Offices for Internet Environment in Government Agencies ;

s. East Java Governor Decree Number 36 of 2003 concerning the Implementation of the Information System and Telematics for the Province of East Java;

t. Situbondo Regent Regulation Number 4 of 2012 concerning Use of Legal Software and Utilization of Open Source Software (OSS) in the Situbondo District Government ;

u. Situbondo Regent Regulation Number 36 of 2015 concerning Guidelines for Implementing the 2016 Regional Budget (APBD).

v. Minister of Health Regulation Number 9 of 2020 Guidelines for Large-Scale Social Restrictions in the Context of Accelerating Handling of Corona Virus Disease 2019 (Covid-19)

w. Circular of the Minister of State Apparatus Empowerment and Bureaucratic Reform (PANRB) Number 19 of 2020 concerning Adjustments to the Work System of State Civil Apparatus in Efforts to Prevent the Spread of Covid-19 Within Government Institutions.

During the covid-19 pandemic, the implementation of e-government was not only carried out in the realm of government but also could be applied in non-governmental agencies (Kapoor \& Kelkar, 2013). So that if this e-government practice can run well, the stakeholders in the OPD and agencies can experience a big benefit so that it can have an impact on improving the quality of public services in Situbondo Regency. The Covid-19 pandemic has changed the face of administrative structures and work patterns in government agencies. To achieve optimal physical distancing, work processes shift from working in the office to working from home (work from home). The development of online-based service, administration, and coordination processes has begun to be made as much as possible in each government agency environment, both government and non-government. responding to the implementation of government administration during the covid-19 pandemic, the government follows the regulation of the minister of health number 9 of 2020 guidelines for large-scale social restrictions in the context of accelerating the handling of the 2019 coronavirus disease (covid-19) in office and industrial workplaces in supporting business continuity in situations pandemic. There are several health protocols that offices, industry, and workers must adhere to in the new normal era.

Meanwhile, specifically for the bureaucracy, issued a circular of the minister for the utilization of the state apparatus and bureaucratic reform (PANRB) number 19 of 2020 concerning 
adjustments to the work system of the state civil apparatus prevent the spread of covid-19 within government institutions. Adjustments are made to create an adaptive work culture with integrity to improve the performance of state civil servants. Based on this Circular, there are two mechanisms for adjusting the work system for ASN Employees in Indonesia, namely: first, the implementation of official duties in the office (work from office), namely carrying out official duties in the office referring to the provisions of laws and regulations in the field of employment; and secondly, the implementation of official duties at home (work from home), namely carrying out official duties carried out at home under the provisions of laws and regulations in the field of employment.

The Covid-19 pandemic is faced with changes in the service and bureaucracy systems. Service change and development is a process by which an organization moves from a present state to a future state that is influenced by environmental changes and unpredictable conditions. These changes and developments are carried out aimed at increasing the effectiveness of services to improve the capabilities of DPO and related agencies in adapting to environmental changes and changes in society and government behavior (Robbins \& Judge, 2013). So that the Situbondo district government seeks to adapt to the change from old habits of serving people with normal conditions to new normal.

\subsection{Development of Public Service Based Electronic (e-Services)}

Regarding the development of public services through e-government, it does not neglect the quality of information. So that the Situbondo district service website is integrated and has met the quality of information that is the spirit of the information submitted to the public, especially the form of public service by the government is closely related to public services. More fully, O'Brien (1998: 26) makes the characteristics of information quality as shown in the following table:

Table 1. Attributes Public Service and Information in Situbondo

\begin{tabular}{|l|l|}
\hline Time Dimension & Information should be provided when needed \\
\hline Unlimited Time & Information must be up to date as it is provided \\
\hline Frequency & Information should be provided as often as possible \\
\hline Time Period & $\begin{array}{l}\text { Information can be provided regarding past, current, and future } \\
\text { situations }\end{array}$ \\
\hline Fill Dimensions & Information must be error-free \\
\hline Accuracy & $\begin{array}{l}\text { Information must be related to special public needs and in a special } \\
\text { time }\end{array}$ \\
\hline Relevance & All necessary information must be provided \\
\hline Completeness & Only the necessary information should be provided \\
\hline Short & $\begin{array}{l}\text { Information can have a particular broad scope, internal or external } \\
\text { focus }\end{array}$ \\
\hline Scope & Information performance can be tracked by measuring fulfilled \\
\hline Performance
\end{tabular}




\begin{tabular}{|c|c|}
\hline & activities, progress, or accumulated resources \\
\hline \multicolumn{2}{|c|}{ Shape Dimensions } \\
\hline Clarity & Information must be provided in a form that is easy to understand \\
\hline Detail & Information can be provided in full or in concise form \\
\hline Order & Information can be arranged in a clear / certain order \\
\hline Display & $\begin{array}{l}\text { Information can be presented in the form of narration, numbers, } \\
\text { graphics, or other forms }\end{array}$ \\
\hline Media & $\begin{array}{l}\text { Information can be provided in the form of printed documents, } \\
\text { video displays, or other media }\end{array}$ \\
\hline
\end{tabular}

In the midst of the Covid-19 pandemic, people are demanding a lot of adaptations in their daily lives, this adaptation also applies to the implementation of public services. So that the concept of e-government develops based on three trends, namely: First, people are free to choose when and from where they want to get in touch with their government to carry out the various transactions or interaction mechanisms needed 24 hours a day and 7 days a week (non-stop); Second, to carry out the interaction mechanism, the public can and may choose multiple channels, both traditional/conventional and the most modern, both those provided by the government and cooperation between the government and the private sector or other non-commercial institutions; and Third, like a conductor in an orchestra, the government, in this case, acts as the main coordinator to enable various things that the society wants to be realized, meaning that the person concerned will create an atmosphere that is conducive to creating an environment for governance as aspired by the people. (Indrajit, 2016).

The policy of the Situbondo district government to prevent the spread of the covid-19 virus has issued many policies which of course have an impact on public service standards implemented by service providers. Increasing public service standards will be one of the efforts to prevent the spread of this virus. Here are the things that are done by the service providers in $\mathrm{k} a$ regencies Situbondo in improving service in the middle of a pandemic, such as:

First: Providing Clear Information Regarding Service Standards on the web that has been provided. Most of the OPD Situbondo district and service provider agencies have online services and an integrated website on the https://situbondokab.go.id/ page, but often this media has not been used to convey service standards, both delivering service products, requirements, mechanisms, procedures, costs, and timeframes, or to convey the activities/performance carried out. Along with this pandemic, providing clear and up-to-date information (always updating information) through various media will greatly assist the public in obtaining clarity of information so that there are no crowds in the service room.

Second: Improve the Online Service Delivery System. Services with an online system are very helpful for the society during this pandemic, but it needs to be paid attention because several services have not been able to convert the system to an online system, for example making a new driving license (SIM), recording e-KTP, and several other services. The online system in this service is carried out in the registration process, completing files, or taking queue numbers, so that service users can arrange the arrival time of the service users. 
Third: Adaptation of Facilities, Infrastructure, and Service Facilities. The existing facilities, infrastructure, and facilities at the service location certainly need adjustments. Adaptations that can be done include providing direct services using Personal Protective Equipment (PPE) such as masks or face shields, applying social distancing by giving distance to queues and waiting rooms, providing hand sanitizers/ hand washing places, and conducting routine sterilization both spraying disinfectants and cleaning the air conditioner regularly. and Fourth: Improve the competence of service implementers. Various adjustments and adaptations are made in the service process, of course, to support this is carried out properly, an increase in the competence of service providers (Human Resources) is made, especially in the use of systems based on information technology and other principles of public service

According to the results of studies and research from the Harvard JFK School of Government, to apply the concept of digitization to the public sector, three elements of success must be owned and considered (Indrajit, 2016). Each of these elements of success is Support, Capacity, and Value. Apart from these three elements, there is an element of successful e-government development in the book Management Information Systems (Nugroho, 2008) put forward by Moon, namely Willingness and Local Culture. Willingness is defined as the willingness or commitment to do something. Local Culture Local culture or local culture that affects the application of e-government is related to the ability to socialize electronic transactions.

Based on the data obtained, there are still some who do not have websites such as remote villages, but through Dinas Kominfo they plan to build a website until it is completed in 2020 . Meanwhile, based on the results of the search for websites in OPD, it seems that the development of e-government in the OPD is still in the web stage up to the stage of transaction and transformation. Websites in this section are managed by OPD - OPD each for their own staff in the IT department, so the implementation of e-government can run effectively. In terms of service time, when compared with the existing service development stages, it can be said that the adoption process in public services using information and communication technology during the covid-19 pandemic took a very fast time to overcome the problems that arise in the middle. The covid-19 pandemic.

In the case observed by Bovens and Zouridis (2002), the change from street-level to screen-level (e-services) or the adoption of information and communication technology in public services takes no less than ten years. One indicator that can be used as a benchmark in assessing the readiness of a Situbondo government in the transformation of public services from street-level to system-level (e-services) is the extent to which the government has provided and developed infrastructure e-government such as internet networks, provision of human resources. Able to manage websites, build connectivity to address the digital divide by providing public access to information technology tools and training. Meanwhile, in terms of connectivity development, it seems that from the research results, the Situbondo district government does not have a strong commitment to it. This is because there is no such thing as Digital Society Centers that can be accessed by the public to interact with the government via electronic means and there are still many villages that do not have websites and networks. 


\section{Conclusion}

The covid-19 pandemic forces all public service sectors to change their habits, new decisions and policies starting from the central to regional levels are published so that ASN can still work in service and work to provide services to the society. The covid-19 pandemic has a very serious impact, especially in terms of performance, considering that so far the ASN work system is conventional, but with the existence of covid-19, it must be turned online and comply with new normal rules. The duties and functions of ASN in a new normal order are carried out while still prioritizing health and safety aspects by implementing health protocols in daily activities. Three elements are of concern in adaptation to the new normal order in ministries, agencies, and regions, namely: adjustment of work systems, human resource support, and infrastructure support. So that in determining and deciding the development and urgency of public services in the midst of the covid-19 pandemic based on policies from the central government, ministries, and regions, Situbondo Regency determines public services and information management, which includes: (1) automation of services such as requesting permits, etc; (2) interactions and transactions through the website, such as payment of PDAM, SIM, and other bills; (3) integration services, data transfer activities are integrated with OPD and institution other.

The development of public services in the Situbondo district government to prevent the spread of the covid-19 virus issued policies which certainly had an impact on public service standards implemented by service providers. Increasing public service standards will be one of the efforts to prevent the spread of this virus. Some of what is done by service providers in Situbondo district in improving services in the midst of a pandemic, namely: First, through the provision of Clear Information Regarding Service Standards on the web that has been provided which is integrated at https://situbondokab.go.id/; Second, through improving the Online Service Delivery System; Third, Adaptation of Facilities, Infrastructure and Service Facilities; and Fourth: Improve the competence of service implementers.

\section{References}

Bovens, M., \& Zouridis, S. (2002). From Street-Level to System-Level Bureaucracles: How Informations adn Communiacation Technology is Transforming Administrative Discretio and Constitutional Control. Public Administration Review, 62(2), 174-184. https://doi.org/10.1111/0033-3352.00168

Darmawan, E., Septian, D., \& Pratama, R. A. (2017). Kebijakan Sektor Publik. Tanjung Pinang: UMRAH Perss.

Deborah, A., Arnaboldi, M., \& Lema, M. D. (2012). Public Money and Management, pp 1-4. https://doi.org/10.1080/09540962.2020.1764206

Dong, E., Du, H., \& Gardner, L. (2020). An Interactive Web-Based Dashboard to Track covid-19 in Real Time. The Lancet Infectious Diseases, 20(5), 533-534. https://doi.org/10.1016/S1473-3099(20)30120-1

Dwiyanto, A. (2010). Manajemen Pelayanan Publik: Peduli, Inklusif, Dan Kolaboratif, 
Yogyakarta, Gadjah Mada University Press.

Indrajit, R. E. (2016). Konsep dan Strategi Electronic Government. Yogyakarta: Andi Yogyakarta.

Kapoor, R., \& Kelkar, N. (2013). E-Governance: Higher Education in Rural Area. National Conference on New Horizons in IT - NCNHIT.

Kompas. (2020). Jokowi Akui Masih Ada Ego Sektoral Menangani Covid-19, Juga Saat $P S B B$. Retrieved from https://nasional.kompas.com/read/2020/04/23/11520051/jokowi-akui-masih-adaego-sektoralmenangani-covid-19-juga-saat-psbb diakses pada 23 April 2020.

Krisyohana, M. (2020). Kesiapan Manajemen ASN untuk WFH. Retrieved from detikNews website: https://news.detik.com/kolom/d-5049198/kesiapan-manajemen-asn-untuk-wfh.

Lewin, K. (1951). Field Theory in Social Science. New York: Harper.

Miles, M. H., \& Saldana. (2014). Qualitative Data Analysis, A Methods Sourcebook (3rd ed.). USA: Sage Publication.

Muchtar, W. (2020). ASN dan New Normal: Pelaksanaan kerja ASN di Tengah Pandemi Covid-19. Retrieved from suara.com website: https://www.suara.com/yoursay/2020/06/03/164058/asn-dan-new-normal-pelaksanaankerja-a sn-di-tengah-pandemi-covid-19.

Nugroho, Eko. (2008). Sistem Informasi Manajemen. Penerbit Andi. Yogyakarta.

O'Brien, J. A. (1998). Introduction to Information System, Irwin/McGraw-Hill. Irwin/McGraw-Hill.

Prasojo, E. (2020). Normal Baru Birokrasi. Kompas. Retrieved from https://kompas.id/baca/opini/2020/06/13/normal-baru-birokrasi/ diakses pada 13 Juni 2020.

Purwanto, A. (2020). Studi Eksplorasi Dampak Work From Home (WFH) Terhadap Kinerja Guru Selama Pandemi Covid-19. EduPsyCouns: Journal of Education, Psychology and Counseling, 2(1). https://doi.org/10.47532/jis.v3i2.181

Robbins, \& Judge. (2013). Organizational Behavior (15th ed.). United States of America: Prentice Hall.

Safroni, M. L. (2012). Manajemen dan Reformasi Pelayanan Publik Dalam Konteks Birokrasi Indonesia, Malang, Aditya Media Publishing, Hal. 15

Sen, A. (2002). Globalization: Past and Present. Lecture 1, Ishizaka Lectures. Tokyo, 18 February 2002.

Shangguan, Z., Wang, M. Y., \& Sun, W. (2020). What Caused the Outbreak of COVID-19 in China : From the Perspective of Crisis Management. International Journal of Environmental Research and Public Health, 17, 1-16. https://doi.org/10.3390/ijerph17093279 


\section{Copyright Disclaimer}

Copyright for this article is retained by the author(s), with first publication rights granted to the journal.

This is an open-access article distributed under the terms and conditions of the Creative Commons Attribution license (http://creativecommons.org/licenses/by/4.0/). 